\title{
An Examination of Herding Behavior in the Brazilian Equity Market
}

\author{
Patrícia Fernanda Correia Lima Signorelli ${ }^{1}$ \\ patricialima_adm@yahoo.com.br | (1D) 0000-0002-2762-0037 \\ Eduardo Camilo-da-Silva ${ }^{1}$ \\ ecamilo@id.uff.br | (D) 0000-0002-0989-7294 \\ Claudio Henrique da Silveira Barbedo ${ }^{2,3}$ \\ claudio.barbedo@bcb.gov.br| (D) 0000-0003-0766-6035
}

\begin{abstract}
The aim of the present study is to investigate herding behavior in the Brazilian stock market. This bias is quite common in times of market downturns and can cause investors to suffer large losses. It is very difficult to effectively identify its real occurrence. Through the method of Chang et al. (2000), it is possible to show that the occurrence of herd behavior is associated with the following phenomena: high trading volume; high volatility, market downturn; and misbalancing of orders. The main contribution of the paper is to identify that herding behavior reacts asymmetrically to the sign of past shocks. The results suggest that an intense selling movement can generate uncertainty in agents, causing them to imitate others in imminent loss periods.
\end{abstract}

\section{KEYWORDS}

Herd Behavior, Market Microstructure, Behavioral Finance

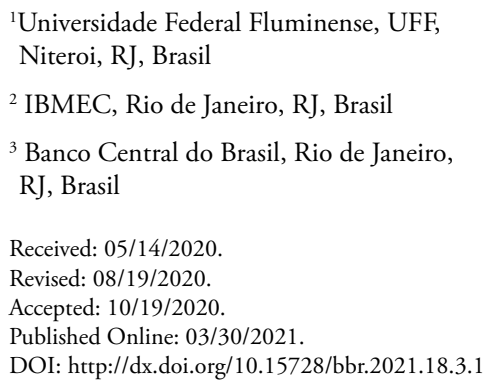




\section{INTRODUCTION}

Behavioral finance has come to the fore since the work of Daniel Kahneman and Amos

Tversky, relaxing the strict requirement of convergence between price and value and recognizing the existence of phenomena associated with decision making by economic agents outside the rational model defined by Von Neumann and Morgenstern in their seminal book Theory of Games and Economic Behavior.

This paper aims to identify the fundamental factors or asymmetric effects that explain the herding phenomenon in the Brazilian market. Herding behavior is a phenomenon in which investors abandon their opinions about the future prospects of the market and try to imitate the behaviors of other investors. This movement is not rational because it prompts investors to buy stocks that have gone up in price (or sell stocks that have fallen) not because they think the price will continue to go up (or fall), but simply because others are doing it. This effect is quite common in times of market downturns and can cause large losses to investors.

This bias is defined by Barnejee (1992) as the act of trying to use the information contained in the decisions made by others, even when one's private information suggests doing something quite different. Silva, Barbedo and Araújo (2015) define herding as the behavior of a group of investors who engage in the trading of a certain asset in the same direction and abandon their previous beliefs in relation to that asset. Araújo Neto et al. (2016) investigated whether people with knowledge of finance and accounting were subject to external influences in trading financial assets and did not find this effect. Majerowicz (2017) examined herding behavior in the Brazilian stock market from 2010 to 2015, a time of economic and political instability, finding no indications of the phenomenon. Finally, Silva and Lucena (2018) studied the bias on the stock market from 2007 to 2016. Their results identified bias during the subprime crisis, more strongly involving small cap stocks.

In general, the works on this topic suggest that the analysis of herding is difficult to measure, and the phenomenon has only been detected in a few studies. Moreover, there is a discrepancy in terms of the evidence found in these previous works. The relevance of this study is intensified, since this phenomenon can cause loss of information, and thus cause prices to deviate from their equilibrium value. It is necessary to understand how prices are formed in the financial market, to understand the quality of information present in the market, and to identify the periods in which the herding effect occurs. Christie and Huang (1995) argued that herding is more prone in periods of market stress since investment decisions vary according to market conditions. Silva and Lucena (2018) corroborated Christie and Huang (1995) by emphasizing that in uncertain moments, investors imitate larger groups. Chiang and Zheng (2010) also identified herd movement during periods of downturns. Bhaduri and Mahapatra (2013) ratified the relationship between herding and downturn periods.

Christie and Huang (1995) claimed that, in the most disturbed periods, individual returns are close to market returns, i.e., there is less private information available, and thus individuals begin to act in accordance with others. In the same way, regarding private information, Cipriani and Guarino (2010) stated that financial agents do not use private information in those periods and start to act according to the crowd. As a consequence, financial markets may not be able to aggregate private information efficiently, causing price misalignments. Therefore, the existence of this phenomenon is capable of affecting the formation of asset prices, that is, prices may not reflect the real value of assets. 
To identify investor behavior in times of market downturns, we performed asymmetry tests to evaluate the existence of the herding effect in relation to high and low trading volume, high and low volatility, good and poor past performance, high and low investor sentiment and also misbalancing of buy and sell orders, this analysis being included in the concept of information asymmetry. ${ }^{1}$ The main contribution of the paper is to identify fundamental factors influencing herding behavior and to verify that herding behavior reacts asymmetrically to the sign of these past shocks. The results show that the herding effect is associated with the occurrence of high trading volume; high volatility of returns; market downturns; and imbalance between transactions with sellers' market dominance.

\section{THEORETICAL FRAMEWORK}

\subsection{HERDING EFFECT}

Liang (2017) defined the herding effect as "the synchronized movement of asset prices in an exuberant and irrational way that is not justified by the fundamentals." Hachicha (2010) described the herding effect as a behavioral trend in which investors observe the attitudes of others. The interest of scholars is to understand why collective information affects the behavior of prices, diverting them from their fundamental-based values, thus presenting profit possibilities. Such information has a strong influence even in relation to private information.

According to Kutchukian (2010), in the occurrence of herding, there is a positively correlated movement, representing a group of investors who follow the same direction. This fact contradicts the following postulates of modern portfolio theory: individuals maximize their expected utility in relation to their risk aversion, and prices correspond to available information. Besides this, the herding effect also contradicts homogeneous information and expectation assumptions, since it occurs in a heterogeneous way and is related to a group of investors.

Furthermore, on price formation, Christie and Huang (1995) stated that believing that the herding effect occurs due to non-rational behavior of investors leads to trading based on inefficient prices, away from equilibrium. Hwang and Salmon (2001) designated as "cascades of information" the fact that market prices may not reflect new information. This event leads to a kind of inefficiency augmented by herd behavior.

According to Chang, Cheng and Khorana (2000), the herding effect can be seen as rational or irrational behavior by investors, depending on the interpretation. With respect to the irrational view, they used the study of Devenow and Welch (1996), indicating that investors ignore their beliefs and opinions by faithfully following other investors. On the other hand, regarding the rational view, they referred to the studies of Scharfstein and Stein (1990) and Rajan (1994), who argued that investors imitate the actions of others, leaving aside private information, aiming at maintaining their capital. Still under the rational view, Hwang and Salmon (2001) stated that the herding effect can be seen in a rational way, since it seeks the maximization of utility, that is, when an investor believes that other investors may be better informed, so not following their actions could lead to lower gains. Chiang and Zheng (2010) find no evidence of herding in Latin American markets. The sample in Brazil covers 70 industries from 1994 to 2009. The authors suggest that crisis sparks herding movement in the country and then produces a spillover effect to neighboring economies. 


\subsection{THE EVOLUTION OF METHODS TO MEASURE THE HERDING EFFECT}

Lakonishok (1992) studied the herding effect by analyzing the degree of correlation of investors'

trading with the purpose of evaluating the effect of transactions on stock prices. Subsequently, Christie and Huang (1995) analyzed the dispersion effect, which corresponds to the cross-sectional standard deviation of returns. This method aims to quantify how far from the average return the individual returns are, corroborating the assumption that investors act according to the group's decisions, as previously mentioned. They also analyzed periods of market stress, believing that this effect occurs more frequently at unusual times.

Christie and Huang (1995) presented the idea that agents' investment decisions will vary according to market conditions. Thus, in more stable periods, the dispersion of individual returns in relation to market returns will tend to increase, since, in this scenario, trading is based on available private information. On the other hand, when there are movements of greater oscillation, the agents' tendency is to leave their opinions aside and follow collective decisions in upcoming trades. Thus, the individual return approaches the market return, and the herding effect can be verified.

Chang, Cheng and Khorana (2000) conducted a study based on Christie and Huang's (1995) method, including the analysis of equity returns through linear regression. Furthermore, they observed both developed and developing financial markets and verified changes in the herding effect in periods involving the economic opening of Asian markets. Hwang and Salmon (2001) also used Christie and Huang (1995)'s studies to define their method and incorporate linear factor models to measure sensitivities of returns. Hwang and Salmon (2004) stated that in the presence of the herd effect, the cross-sectional variation of betas remains low. Thus, investors tend to follow the market portfolio.

Hachicha (2010) highlighted the existence of two currents in the literature on the herd effect, both mentioned above. This distinction is between the studies of Lakonishok et al. (1992) and Wermers (1995) - who analyzed the possibility of individuals' following others, measured by trading volume - and the studies of Christie and Huang (1995), Chang et al. (2000) and Hwang and Salmon $(2001 ; 2004)$, who focused on the analysis of the herding effect at the market level, i.e., choosing specific assets, based on the analysis of the cross-sectional dispersion of betas. Hachicha (2010) and Lakonishok, Shleifer and Vishny (1992) found evidence of the herding effect in stocks of small companies, explained because there is less information available, so investors begin to look at the attitudes of other market agents.

\subsection{Previous Brazilian studies}

In Brazil, several papers have analyzed the herding effect in the stock market. Silva and Lucena (2018) identified the herding effect based on the cross-sectional absolute deviation of returns (CSAD) model, proposed by Chang, Cheng and Khorana (2000). Their results corroborated the hypothesis that, in moments of uncertainty, investors are more insecure and tend to act according to the behavior of larger groups.

Zulian et al. (2012) analyzed the herding behavior in stock mutual funds in Brazil. The results suggested the occurrence of the herding effect with similar intensity as in countries such as the United Kingdom, Germany and the United States. Tariki (2014) investigated herding behavior of mutual funds in the Brazilian market, using the method developed by Lakonishok et al. (1992), from September 2007 to October 2013, finding strong evidence of the herding effect with intensity that varies according to the size and the capitalization of the fund. Silva (2017) tested 
the method proposed by Chang, Cheng and Khorana (2000) and the cross-sectional absolute deviation of returns (CSAD) model. The herding effect was identified during the 2008 crisis.

\subsection{Christie And Huang's method (1995)}

In this model, the herding effect is measured by means of the standard deviation, or crosssectional dispersion of asset returns in relation to the average market return.

$$
\operatorname{CSSD}_{t}=\sqrt{\frac{1}{\mathrm{~N}-1} \sum_{\mathrm{i}=1}^{\mathrm{N}}\left(\mathrm{R}_{\mathrm{i}, \mathrm{t}}-\mathrm{R}_{\mathrm{m}, \mathrm{t}}\right)^{2}}
$$

where, CSSD $t$ is the cross-sectional standard deviation, $R i, t$ is the return on assets $\mathrm{i}$ in period $\mathrm{t}$, $R m, t$ is the average transversal return of the market portfolio, and $\mathrm{N}$ is the number of assets to be analyzed. This method can be summarized as a linear regression analysis in which the calculated CSSD corresponds to the dependent variable there are two categorical variables (dummies), corresponding to the tails of the market return, both positive and negative. Thus, market dispersion is tested, according to Christie and Huang (1995), through the following regression:

$$
\operatorname{CSSD}_{t}=\alpha+\beta_{1} D_{t}^{L}+\beta_{2} D_{t}^{U}+\varepsilon_{t}
$$

where the dummy variables are $D_{t}^{L}=1$, if the market returns are at the lower end of the distribution or 0 otherwise and $D_{t}^{U}=1$, if the market returns are at the upper end of the distribution or 0 otherwise, and the alpha coefficient represents the average dispersion of the sample.

The method tests whether, in the presence of the herd effect, investors move closer to the market consensus and therefore the individual return remains close to the market return. Considering as true the premise that investors are more likely to suppress their beliefs during troubled periods, acting in accordance with the market consensus, they expected to find the coefficients $\beta 1$ and $\beta 2$ to be negative and statistically significant.

\subsection{Chang, Cheng and Khorana's method (2000)}

This method is applied to identify the presence of the herd effect, based on the cross-sectional absolute deviation of returns (CSAD) model, which uses the mean of absolute deviations from returns, considered in both methods to be the best measure of dispersion. This model tests whether investors, at times, tend to set aside their beliefs and opinions to follow the decisions of a group, so that, in these periods, the individual's return would remain close to the general market return.

Chang, Cheng and Khorana (2000) proposed this method based on Christie and Huang (1995), presented as less rigorous alternative approach, since they expanded the study by including the analysis of the behavior of the return on equity through linear regression. Furthermore, they stated that in all markets, the rise in the dispersion of returns (estimated by CSAD) compared to the aggregate return of the market is larger at times of market upturns than at times of decline. This is justified because the market tends to react more quickly in the presence of negative macroeconomic news. In the presence of small stocks, the repercussion to positive news happens later. In comparison with the previous method, this model was chosen because it is a less intuitive measure, and thus less sensitive to the presence of discrepant values. It is estimated as follows:

$$
\operatorname{CSAD}_{t}=\frac{\sum\left|\mathrm{R}_{\mathrm{i}, \mathrm{t}}-\mathrm{R}_{\mathrm{m}, \mathrm{t}}\right|}{N-1}
$$


where CSAD $_{\mathrm{t}}$ is the cross-sectional absolute deviation of returns, $R_{i, t}$, regarding to the return of an equal-weighted realized return of the market portfolio, $R_{m}$, in period $t$, and $\mathrm{N}$ is the number of assets to be analyzed.

This method relies on a modified regression model, in which an asymmetrical parameter is added to identify a probable nonlinearity between the dispersion of individual asset returns and the market returns. The authors argued that in the presence of the herd effect, in stressed periods, there may be non-proportional growth or decrease in the CSAD measure with an increase of $|\mathrm{Rm}, \mathrm{t}|$. However, in the absence of this behavior, this relationship is linear and directly proportional, following the postulates of the asset pricing model. This nonlinear relationship between dispersion and return in the market, which characterizes the presence of the herd effect, is detected from the following regression equation:

$$
\operatorname{CSAD}_{t}=\alpha+\beta_{1}\left|\mathrm{R}_{\mathrm{m}, \mathrm{t}}\right|+\beta_{2} R_{m, t}^{2}+\varepsilon_{t}
$$

Regarding the above model, the herd effect is verified if the coefficient $\beta_{2}$ is negative and statistically significant, due to the existence of a nonlinear relationship between asset dispersion and market return. In this scenario, it can be seen that the CSAD will grow at decreasing rates or will decrease. However, if the coefficient $\beta_{2}$ is positive (or negative, but not significant), this denotes the absence of the herding effect and confirms the assumptions of the CAPM model. The inclusion of the quadratic term is responsible for making the method more sensitive and rigorous. The model of Chang, Cheng and Khorana (CCK) allows investigating the herding effect in an asymmetric way in the financial market, either as a function of the returns or a function of the volume traded, for example. Based on the market return, to verify the asymmetric existence of the herding behavior, it is necessary to estimate the following specifications:

\section{Asymmetry Test - Market Return:}

$$
\begin{gathered}
C S A D_{t}^{U P}=\alpha+\beta_{1}^{U P}\left|R_{m, t}^{U P}\right|+\beta_{2}^{U P}\left(R_{m, t}^{U P}\right)^{2}+\varepsilon_{t} \\
C S A D_{t}^{D}=\alpha+\beta_{1}^{D}\left|R_{m, t}^{D}\right|+\beta_{2}^{D} \quad\left(R_{m, t}^{D}\right)^{2}+\varepsilon_{t}
\end{gathered}
$$

where $C S A D_{t}^{U P}\left(C S A D_{t}^{D}\right)$ is the cross-sectional absolute deviation of returns, $R_{i, t}$, relative to the equal-weighted market portfolio return, $R_{m}$, at time $t$, when $R_{m}$ is up (down) and $R_{m, t}^{U P}\left(R_{m, t}^{D}\right)$ is the absolute value of an equal-weighted realized return of the market portfolio, at time $t$, when the market is upturn (downturn). All variables are estimated on a daily basis.

\subsection{Trading imbalance PiCture (TIP)}

The TIP, presented by Pereira, Camilo-da-Silva and Barbedo (2020), measures the imbalance between the numbers of buy and sell orders of the Brazilian Stock Exchange (B3). A distinction should be made between the expressions "order imbalances" and "transaction flow imbalances". The former is used in quote-driven markets, while the latter is used in stock exchanges without market makers, or order-driven markets. The imbalance between buy and sell orders has an impact on the formation of asset prices (Cont, Kubanov and Stoikov, 2014). This effect occurs when, for example, there are more orders for purchase than for sale. The same thing occurs in the opposite situation. Another point of influence is that order imbalances sometimes indicate private information, which would reduce liquidity, considering the increase in inventory costs, and might also permanently move the market price (Kyle, 1985). According to Chordia et al. 

defined market order imbalance as daily aggregate buy orders minus sell orders divided by the total number of transactions on a given day.

The TIP is an index denoted as the difference between the numbers of buyer-initiated trades and seller-initiated trades, divided by the difference between the total number of trades and the number of trades that do not have an aggressor (neutral) on a certain day and in a certain asset. It should be noted that this index includes the number of transactions that do not present an aggressor, that is, neutral, thus eliminating the residual error of this variable. The inclusion of this indicator aims to understand how the imbalance affects the market, ex-ante, identifying the moments of occurrence, and ex-post, testing the capacity to determine the herd effect.

$$
\mathrm{TIP}=\frac{\text { Buyer initiated trades }- \text { Seller initiated trades }}{\text { Total trades }- \text { Neutral trades }}
$$

\section{METHODOLOGY}

\subsection{SAMPLE AND DATA SOURCE}

In this first phase of data and sample treatment, we selected the most liquid daily closing stocks. To apply the methods developed by Christie and Huang (1995) and Chang, Cheng and Khorana (2000), the liquidity index (IL) was adopted as the criterion for choosing the stocks (Argolo et al., 2012). We select 173 stocks with IL higher than 0,01. For calculation of the TIP, the intraday information on the transactions carried out in B3 was used. This database also allows identification of the trigger in each trade carried out. The study period runs from January 2008 to May 2019. BM\&FBovespa database is composed of three parts. The first two parts include data regarding market participants' buy and sell orders, i.e., the millionth of a second of each trade, the stock ticker, the financial volumes and the stock price. Part three contains data regarding traded stocks as order type (buy or sell) and order timestamp. From this data, we accurately identify the aggressor, defined as which side is demanding liquidity, the buyer (a buyer-initiated order) or the seller (a seller-initiated order).

\subsection{HeRding EFFECT MEASUREMENT AND TESTING}

To identify the herd effect, two methods were used: the first, developed by Christie and Huang (1995), known as CSSD (cross-sectional standard deviation), captures the herding effect through the standard deviation or cross-sectional dispersion of asset returns relative to the average market return. The second method was that presented by Chang, Cheng and Khorana (2000), based on the cross-sectional absolute deviation of returns (CSAD) model. This model uses the mean of the absolute cross-sectional deviations of returns.

To apply Christie and Huang's (1995) method, we estimated the daily CSSD and the days on which the Brazilian Stock Exchange Index (Ibovespa) showed its largest changes in returns, $D_{t}^{U}$ and $D_{t}^{L}$. In this case, the daily returns that are equal to 1 , at the upper or lower end of the distribution, represent the highest $10 \%$ positive or negative variations of the return in the period. After this definition, linear regressions were estimated using the $\mathrm{R}$ software to test the significance of $\beta 1$ and $\beta 2$. 
For the Chang, Cheng and Khorana (2000) method, the daily CSAD and dummies were also estimated for a later asymmetry test. When the herding effect was identified, their relationship with possibly relevant variables such as trading volume (high or low), volatility (high or low), returns (positive or negative), imbalance of orders (buy and sell) and investor sentiment (high or low) were tested. For the asymmetric tests, the periods corresponding to the $25 \%$ highest and the $25 \%$ lowest values found in certain circumstances in the market were used, such as: volume, volatility, return, trade misbalancing and investor sentiment. In view of this, the following tests were applied to check the asymmetric presence of the herd effect:

\section{Asymmetry test - volume traded:}

Based on the trading volume (high or low), the following regressions were estimated to check the asymmetric herding effect:

$$
\begin{aligned}
& C S A D_{t}^{V H}=\alpha+\beta_{1}^{V H}\left|R_{m, t}^{V H}\right|+\beta_{2}^{V H}\left(R_{m, t}^{V H}\right)^{2}+\varepsilon_{t} \\
& C S A D_{t}^{V L}=\alpha+\beta_{1}^{V L}\left|R_{m, t}^{V L}\right|+\beta_{2}^{V L}\left(R_{m, t}^{V L}\right)^{2}+\varepsilon_{t}
\end{aligned}
$$

where $C S A D_{t}^{V H}\left(C S A D_{t}^{V L}\right)$ is the cross-sectional absolute deviation of returns, $R_{i, t}$, relative to the equal-weighted market portfolio return, $R_{m}$, at time $t$, when trading volume is high (low) and $R_{m, t}^{V H}\left(R_{m, t}^{V L}\right)$ is the absolute value of an equal-weighted realized return of the market portfolio, at time $t$, when trading volume is high (low). All variables are estimated on a daily basis.

\section{Asymmetry test - volatility:}

Following the same line of reasoning, in this test the analysis was performed according to the volatility (high or low), applying the equations below:

$$
\begin{aligned}
C S A D_{t}^{\sigma H} & =\alpha+\beta_{1}^{\sigma H}\left|R_{m, t}^{\sigma H}\right|+\beta_{2}^{\sigma H}\left(R_{m, t}^{\sigma H}\right)^{2}+\varepsilon_{t} \\
C S A D_{t}^{\sigma L} & =\alpha+\beta_{1}^{\sigma L}\left|R_{m, t}^{\sigma L}\right|+\beta_{2}^{\sigma L}\left(R_{m, t}^{\sigma L}\right)^{2}+\varepsilon_{t}
\end{aligned}
$$

where as in Equation (8) and (9), $\sigma \mathrm{H}$ represents the periods when the market showed high volatility and $\sigma \mathrm{L}$ denotes periods with low volatility.

\section{Asymmetry test - returns:}

Based on the market return (positive or negative), to check the asymmetric existence of herd behavior, the following specifications were estimated:

$$
\begin{gathered}
C S A D_{t}^{U P}=\alpha+\beta_{1}^{U P}\left|R_{m, t}^{U P}\right|+\beta_{2}^{U P}\left(R_{m, t}^{U P}\right)^{2}+\varepsilon_{t} \\
C S A D_{t}^{D}=\alpha+\beta_{1}^{D}\left|R_{m, t}^{D}\right|+\beta_{2}^{D}\left(R_{m, t}^{D}\right)^{2}+\varepsilon_{t}
\end{gathered}
$$

where as in Equation (8) and (9),UP and D correspond to upward and downward past performance periods, respectively. 


\section{Asymmetry test - imbalance of orders:}

From the intraday data of B3, the numbers of buyer initiated, seller initiated and neutral trades of each asset for each day were estimated.

$$
\begin{aligned}
& C S A D_{t}^{T I P+}=\alpha+\beta_{1}^{T I P+}\left|R_{m, t}^{T I P+}\right|+\beta_{2}^{T I P+}\left(R_{m, t}^{T I P+}\right)^{2}+\varepsilon_{t} \\
& C S A D_{t}^{T I P-}=\alpha+\beta_{1}^{T I P-}\left|R_{m, t}^{T I P-}\right|+\beta_{2}^{T I P-}\left(R_{m, t}^{T I P-}\right)^{2}+\varepsilon_{t}
\end{aligned}
$$

where as in Equation (8) and (9),TIP + and TIP- represent the periods of higher buying imbalance and higher selling imbalance, respectively.

\section{Asymmetry test - investor sentiment:}

Finally, the following analyses were added to test investor sentiment.

$$
\begin{aligned}
& C S A D_{t}^{S+}=\alpha+\beta_{1}^{S+}\left|R_{m, t}^{S+}\right|+\beta_{2}^{S+}\left(R_{m, t}^{S+}\right)^{2}+\varepsilon_{t} \\
& C S A D_{t}^{S-}=\alpha+\beta_{1}^{S-}\left|R_{m, t}^{S-}\right|+\beta_{2}^{S-}\left(R_{m, t}^{S-}\right)^{2}+\varepsilon_{t}
\end{aligned}
$$

where as in Equation (8) and (9),S+ and $S$ - correspond to the best and the worst investor sentiment periods, measured by the kurtosis of each asset's return distribution.

All the regression models were run using the ordinary minimum squares method. In the next section, the results of the analyses are presented. After the asymmetry tests, residual tests were performed to evaluate homoscedasticity (Breusch-Pagan), normality (Jarque-Bera) and independence (Durbin-Watson and Breusch-Godfrey).

\section{RESULTS}

\subsection{HeRding EFFECT}

Table 1 shows the results of CSSD and CSAD methods from 2008 to 2018. In the CSSD method, when the market return is in the top $10 \%$ (or 90\%) and when the market return is in the bottom $10 \%$ (or 90\%) the coefficient is almost always statistically significant, but not negative. In the CSAD method, from 2009-2015 period and in the year 2018, the coefficient $\beta_{2}$ is always negative and statistically significant. We also perform the Chiang and Zheng (2010) method as a robustness check.

This result corroborates Almeida's (2011) statement that although the methods are similar, they do not always present the same result. The results obtained from the CSAD method, in the 20092015 period and in the year 2018, indicates the presence of the herd effect. These results show that the CSAD measure is rising or falling nonlinearly in relation to the average market return.

In 2008 , and in the 2016-2017 period, the coefficient $\beta_{2}$ is negative, but not statistically significant. Thus, it was not possible to detect the occurrence of the herding effect, while, at the same time, it was not possible to contradict the assumptions of the linear and directly proportional relationship between the dispersion and market return.

It should be noted that the herding effect was not identified in the year of the crisis, but was in the following year, when there was a significant rebound of prices in the Brazilian stock market. Therefore, a detailed analysis of this period is required for a better understanding of the herding behavior in low and high moments of the Ibovespa. 
Table 1

Estimates of herding behavior from CSSD and CSAD methods

\begin{tabular}{|c|c|c|c|c|c|c|c|}
\hline & \multicolumn{3}{|c|}{ CSSD } & \multicolumn{2}{|c|}{$\begin{array}{l}\text { CSAD } \\
\text { CSAD }\end{array}$} & \multicolumn{2}{|c|}{ CSAD } \\
\hline & \multicolumn{3}{|c|}{$\operatorname{CSSD}_{t}=\alpha+\beta_{1} D_{t}^{L}+\beta_{2} D_{t}^{U}+\varepsilon_{t}$} & \multicolumn{2}{|c|}{$\operatorname{CSAD}_{t}=\alpha+\beta_{1}\left|R_{m, t}\right|+\beta_{2} R_{m, t}^{2}+\varepsilon_{t}$} & \multicolumn{2}{|c|}{$C S A D_{t}=\alpha+\beta_{1} R_{m, t}++\beta_{2}\left|R_{m, t}\right|+\beta_{3} R_{m, t}^{2}+\varepsilon_{t}$} \\
\hline Year & & Coeff. & Prob. & Coeff. & Prob. & Coeff. & Prob. \\
\hline \multirow{3}{*}{2008} & '90\%' & 0,0323 & $<2 \mathrm{e}-16^{* * *}$ & 0,6510 & $<2 \mathrm{e}-16^{* * *}$ & 0,4016 & $6,6 \mathrm{e}-05^{* * *}$ \\
\hline & & & & & & 0,6824 & $<2 \mathrm{e}-16^{* * *}$ \\
\hline & $' 10 \% '$ & 0,0285 & $<2 \mathrm{e}-16^{* * *}$ & $-0,3485$ & 0,257 & $-0,7159$ & $0,0222 *$ \\
\hline \multirow{3}{*}{2009} & $' 90 \%$ & 0,0252 & $<2 \mathrm{e}-16^{* * *}$ & 0,7492 & $<2 \mathrm{e}-16^{* * *}$ & 0,0236 & $0,048625 *$ \\
\hline & & & & & & 0,7552 & $<2 \mathrm{e}-16^{* * *}$ \\
\hline & $' 10 \% `$ & 0,0224 & $<2 \mathrm{e}-16^{* * *}$ & $-3,1489$ & $0,00142^{* *}$ & $-3,3765$ & $6,5 \mathrm{e}-04^{* * *}$ \\
\hline \multirow{3}{*}{2010} & $' 90 \% '$ & 0,0077 & $1,04 \mathrm{e}-09^{* * *}$ & 0,7571 & $<2 \mathrm{e}-16^{* * *}$ & $-0,0015$ & 0,918 \\
\hline & & & & & & 0,7577 & $<2 \mathrm{e}-16^{* * *}$ \\
\hline & $' 10 \% '$ & 0,0084 & $3,33 \mathrm{e}-11^{* * *}$ & $-7,2478$ & $6 \mathrm{e}-06{ }^{* * *}$ & $-7,2708$ & $7,28 \mathrm{e}-06^{* * *}$ \\
\hline \multirow{3}{*}{2011} & $' 90 \% '$ & 0,0094 & $6,42 \mathrm{e}-13^{* * *}$ & 0,5922 & $<2 \mathrm{e}-16^{* * *}$ & 0,0269 & $0,038104^{*}$ \\
\hline & & & & & & 0,5822 & $<2 \mathrm{e}-16^{* * *}$ \\
\hline & $' 10 \% '$ & 0,0087 & $2,11 \mathrm{e}-11^{* * *}$ & $-2,8388$ & $5 e-05^{* * *}$ & $-2,4728$ & $0,00061^{* * *}$ \\
\hline \multirow{3}{*}{2012} & $' 90 \% '$ & 0,0091 & $1,19 \mathrm{e}-09^{* * *}$ & 0,8169 & $<2 \mathrm{e}-16^{* * *}$ & 0,0043 & 0,808 \\
\hline & & & & & & 0,8192 & $<2 \mathrm{e}-16^{* * *}$ \\
\hline & '10\%' & 0,0078 & $1,22 \mathrm{e}-07^{* * *}$ & $-9,1488$ & $1 \mathrm{e}-05^{* * *}$ & $-9,2654$ & $1,75 \mathrm{e}-05^{* * *}$ \\
\hline \multirow{3}{*}{2013} & $' 90 \% ’$ & 0,0093 & $2,29 \mathrm{e}-07^{* * *}$ & 0,8155 & $<2 \mathrm{e}-16^{* * *}$ & 0,0361 & $0,0393^{*}$ \\
\hline & & & & & & 0,8120 & $<2 \mathrm{e}-16^{* * *}$ \\
\hline & $' 10 \% '$ & 0,0074 & $3,84 \mathrm{e}-05^{* * *}$ & $-10,3100$ & $1 \mathrm{e}-05^{* * *}$ & $-10,0470$ & $1,93 \mathrm{e}-05^{* * *}$ \\
\hline \multirow{3}{*}{2014} & $' 90 \% '$ & 0,0097 & $4,67 \mathrm{e}-07^{* * *}$ & 0,6553 & $<2 \mathrm{e}-16^{* * *}$ & 0,0230 & 0,15224 \\
\hline & & & & & & 0,6570 & $<2 \mathrm{e}-16^{* * *}$ \\
\hline & $' 10 \% `$ & 0,0091 & $2,03 \mathrm{e}-06^{* * *}$ & $-4,4811$ & $\mathbf{0 , 0 0 9}$ ** $^{* *}$ & $-4,5573$ & $0,00782^{* *}$ \\
\hline \multirow{3}{*}{2015} & $' 90 \% ’$ & 0,0098 & $0,00121^{* *}$ & 0,9583 & $<2 \mathrm{e}-16^{* * *}$ & 0,0524 & $0,0364^{*}$ \\
\hline & & & & & & 1,0120 & $<2 \mathrm{e}-16^{* * *}$ \\
\hline & $' 10 \% `$ & 0,0058 & 0,05301 & $-15,8913$ & $1 \mathrm{e}-05^{* * *}$ & $-0,1813$ & $1,85 \mathrm{e}-06^{* * *}$ \\
\hline \multirow{3}{*}{2016} & $' 90 \% ’$ & 0,0144 & $1,24 \mathrm{e}-05^{* * *}$ & 0,5612 & $4 \mathrm{e}-12^{* * *}$ & 0,0316 & 0,0166 \\
\hline & & & & & & 0,5743 & $1,83 \mathrm{e}-12^{* * *}$ \\
\hline & $' 10 \% `$ & 0,0066 & $0,042 *$ & $-2,0799$ & 0,248 & $-2,5743$ & 0,160 \\
\hline \multirow{3}{*}{2017} & $' 90 \%$ & 0,0066 & $0,000986^{* * *}$ & 0,5298 & $<2 \mathrm{e}-16^{* * *}$ & 0,0100 & 0,72 \\
\hline & & & & & & 0,5246 & $<2 \mathrm{e}-16^{* * *}$ \\
\hline & '10\%' & 0,0063 & $0,001570^{* *}$ & $-1,4124$ & 0,133 & $-1,2490$ & 0,232 \\
\hline \multirow{3}{*}{2018} & '90\%' & 0,0054 & $0,0151^{*}$ & 0,8016 & $4 \mathrm{e}-12^{* * *}$ & 0,0306 & 0,319 \\
\hline & & & & & & 0,7862 & $1,55 \mathrm{e}-11^{* * *}$ \\
\hline & $' 10 \% ’$ & 0,0023 & 0,2924 & $-15,3000$ & $1 \mathrm{e}-05^{* * *}$ & $-0,1452$ & $4,91 \mathrm{e}-05^{* * *}$ \\
\hline
\end{tabular}

Source: Research data (2018) 
BBR

18

246

The CCSD method did not identify the herding effect in any year. The CSAD method identified the effect from 2009 to 2015 and in 2018. The results of the approach of Chiang and Zheng (2010) is presented in the third column as a robustness check. In the CSAD method, the negative and significant coefficient relative to the squared return shows that in these years the dispersion of returns decreased with the increase in market return, which contradicts the linear market model and indicates the presence of herd effect. The results show a persistence level of herding behavior over time.

\subsection{HeRding EFFECT AND MARKET CHARACTERISTICS}

Christie and Huang (1995) presented the idea that agents' investment decisions adjust according to market conditions. In this scenario, the purpose of this analysis is to diagnose how the herding effect behaves in relation to certain market conditions. Thus, asymmetry tests were carried out to evaluate the existence of the herding effect in relation to the periods that corresponded to the $25 \%$ highest and $25 \%$ lowest values of trading volume, volatility, bull and bear market, misbalancing of buy and sell orders, and investor sentiment.

The asymmetry tests were performed by selecting for each variable to be tested the days on which the situation evaluated occurred and running the regression of the CSAD model for this sample. In case the herding effect is identified by a negative coefficient and significant for the term "square of the return", it is assumed that the variable is related to the presence of the herd effect. To ensure the validity of the regression, residual diagnostics assessing homoscedasticity, normality, and independence were performed. Independence was checked by the Durbin-Watson and Breusch-Godfrey tests, while for homoscedasticity, the Breusch-Pagan test was applied to determine whether the variances of errors were equal, an assumption that must be met.

The normality of the residuals was verified through the Jarque-Bera test. For each analysis, a regression was estimated using the method of Chang, Cheng and Khorana (2000).

\subsubsection{Herding effect and trading volume}

Hachicha (2010) proposed a new measure, inspired by the approach of Lakonishok, Shleifer and Vishny (1992) and Hwang and Salmon (2004), using turnover to examine the herding effect on the Toronto stock exchange. Similarly, in this study, we analyzed whether the presence of the herding effect differs in terms of the trading volume in the stock market, analyzed according to asymmetry.

As explained in Table 1 about the CSAD method, the coefficient $\beta_{2}$ should be negative and statistically significant to indicate a herding effect. For periods of high trading volume, the existence of a negative and statistically significant $\beta 2$ coefficient was verified, compatible with the herding behavior hypothesis. These results corroborate Hachicha (2010), who concluded that a large volume of business is a necessary condition for the existence of the herding effect among investors. However, the same cannot be said for low trading volume. Christie and Huang (1995) stated that in the existence of small-cap stocks the repercussion to positive news happens belatedly. This argument may explain the absence of herding effect in moments of low volume. Thus, investors, in markets with lower trading volume would be less likely to take action in line with others, with the presence of irrationality in decisions. The Durbin-Watson and BreuschGodfrey null hypothesis is that the residuals are not autocorrelated and the Breusch-Pagan null hypothesis is that the residual variances are all equal. It was possible to confirm the independence and homoscedasticity of the residuals, according to Tables 2 and 3. 
Table 2

Results of the CSAD model considering high trading volume

\begin{tabular}{lcclll}
\hline & Coefficient & P-Value & \multicolumn{4}{l}{ Residual Diagnostics } \\
\hline Intercept & 0.000903953 & 0.2376 & Durbin-Watson & 1.8557 & Do not reject H0 \\
$\beta 1$ & 0.017836223 & 0.8132 & Breusch-Godfrey & 0.5587 & Do not reject H0 \\
$\beta 2$ & -3.066689255 & 0.0197 & Breusch-Pagan & 2.4E-01 & Do not reject H0 \\
\hline
\end{tabular}

Source: Research data (2018)

Table 3

Results of the CSAD model considering low trading volume

\begin{tabular}{lcclll}
\hline & Coefficient & P-Value & \multicolumn{2}{l}{ Residual Diagnostics } & \\
\hline Intercept & 0.001344269 & 0.0925 & Durbin-Watson & 2.0855128 & Do not reject H0 \\
$\beta 1$ & -0.188867169 & 0.1363 & Breusch-Godfrey & 0.1222209 & Do not reject H0 \\
$\beta 2$ & 6.279777377 & 0.1086 & Breusch-Pagan & 0.1380 & Do not reject H0 \\
\hline
\end{tabular}

Source: Research data (2018)

\subsubsection{Herding effect and volatility}

According to Christie and Huang (1995), at times of greater stock market oscillation, there is a tendency for individuals to put aside their beliefs and start following the decisions of others. To test whether this hypothesis is valid in the Brazilian stock market, we conducted an analysis of the moments of higher and lower market volatility, as shown in Tables 4 and 5.

Table 4

Results of the CSAD model considering high market volatility

\begin{tabular}{lcclll}
\hline & Coefficient & P-Value & \multicolumn{2}{l}{ Residual Diagnostics } & \\
\hline Intercept & 0.001832112 & 0.0603 & Durbin-Watson & 2.133681633 & Do not reject H0 \\
$\beta 1$ & 0.037967946 & 0.7424 & Breusch-Godfrey & 0.268953812 & Do not reject H0 \\
$\beta 2$ & -4.709270376 & 0.0745 & Breusch-Pagan & 0.362383126 & Do not reject H0 \\
\hline
\end{tabular}

Source: Research data (2018)

Table 5

Results of the CSAD model considering low market volatility

\begin{tabular}{lcclll}
\hline & Coefficient & P-Value & \multicolumn{2}{l}{ Residual Diagnostics } & \\
\hline Intercept & 0.002122872 & 0.0024 & Durbin-Watson & 1.9696009 & Do not reject H0 \\
$\beta 1$ & -0.535608253 & 0.0000 & Breusch-Godfrey & 0.2065721 & Do not reject H0 \\
$\beta 2$ & 20.024163 & 0.0000 & Breusch-Pagan & $2.21 \mathrm{E}-56$ & Reject H0 \\
\hline
\end{tabular}

Source: Research data (2018) 
BBR

18

248

As the previous table, and from now on, we expect a coefficient $\beta_{2}$ negative and statistically significant to identify a herding effect and to confirm the independence and homoscedasticity of the residuals. As can be seen in Table 4, in periods of high volatility the $\beta 2$ coefficient is negative and significant, indicating the presence of herd effect. These results corroborate the study by Silva, Barbedo and Araújo (2015), who stated that this phenomenon is commonly associated with periods of greater volatility and is attributed to the human component in asset trading. On the other hand, in the periods of low volatility presented in Table 5 , the coefficient $\beta 2$ is positive, which rejects the existence of the herd effect. Besides, the homoskedasticity is rejected through the Breusch-Pagan test and heteroskedasticity is assumed in low volatility periods. This suggests that if the market presents low volatility, this allows investors to follow their own conclusions without the need for sudden actions.

\subsubsection{Herding effect and market performance}

Table 6 shows there is no effect in periods of good past performance. This analysis corroborates Hachicha (2010), who argued that in periods of low risk and rising stock prices, the herding effect decreases. Table 7 shows the presence of the herding during market downturn, despite heteroskedasticity is assumed in these periods.

This fact corroborates the idea that the market is more prone to react quickly when faced with negative news. In other words, at times of decline, the market tends to act synchronously, presenting herding behavior.

Table 6

Results of the CSAD model considering good market performance

\begin{tabular}{llllll}
\hline & Coefficient & P-Value & \multicolumn{2}{l}{ Residual Diagnostics } & \\
\hline Intercept & 0.001115215 & 0.5080 & Durbin-Watson & 1.6367178 & Reject H0 \\
$\beta 1$ & -0.25565071 & 0.0772 & Breusch-Godfrey & 0.0500165 & Do not reject H0 \\
$\beta 2$ & -1.191689336 & 0.6458 & Breusch-Pagan & 1.12 E-08 & Reject H0 \\
\hline
\end{tabular}

Source: Research data (2018)

Table 7

Results of the CSAD model considering poor market performance

\begin{tabular}{lcclll}
\hline & Coefficient & P-Value & \multicolumn{2}{l}{ Residual Diagnostics } \\
\hline Intercept & -0.000208127 & 0.8707 & Durbin-Watson & 1.9285454 & Do not reject H0 \\
$\beta 1$ & 0.364755756 & 0.0003 & Breusch-Godfrey & 0.812949 & Do not reject H0 \\
$\beta 2$ & -5.337882441 & 0.0009 & Breusch-Pagan & $3.36 E-02$ & Reject H0 \\
\hline
\end{tabular}

Source: Research data (2018) 


\subsubsection{Herding effect and misbalancing of orders}

In order to understand herding effect through misbalancing of orders, we measured periods with higher and lower TIPs. Table 8 shows that the herding effect is not observed when the market imbalance was motivated by buy orders, but Table 9 indicates the occurrence of herding effect when the market imbalance is motivated by sell orders. This suggests that an intense selloff movement can generate uncertainty in agents, causing them to get rid of their shares.

Table 8

Results of the CSAD model considering imbalance motivated by a higher number of buy orders

\begin{tabular}{lcclll}
\hline & Coefficient & P-Value & \multicolumn{2}{l}{ Residual Diagnostics } & \\
\hline Intercept & 0.002699938 & 0.0004 & Durbin-Watson & 1.9356857 & Do not reject H0 \\
$\beta 1$ & -0.364864273 & 0.0000 & Breusch-Godfrey & 0.3518072 & Do not reject H0 \\
$\beta 2$ & 2.579607716 & 0.1781 & Breusch-Pagan & $2.23 \mathrm{E}-02$ & Reject H0 \\
\hline
\end{tabular}

Source: Research data (2018)

Table 9

Results of the CSAD model considering imbalance motivated by a higher number of sell orders

\begin{tabular}{lcclll}
\hline & Coefficient & P-Value & \multicolumn{2}{l}{ Residual Diagnostics } \\
\hline Intercept & -0.001660192 & 0.0219 & Durbin-Watson & 2.024814071 & Do not reject H0 \\
$\beta 1$ & 0.354638063 & 0.0000 & Breusch-Godfrey & 0.322457779 & Do not reject H0 \\
$\beta 2$ & -5.652267135 & 0.0000 & Breusch-Pagan & $4.22 \mathrm{E}-02$ & Reject H0 \\
\hline
\end{tabular}

Source: Research data (2018)

These results confirm what was verified in market downturn periods, since the periods of low returns indicated the presence of herd effect. This fact corroborates Martins, Paulo and Albuquerque (2013), who stated that few trades are expected on days when no information events and good news occur, while more sell orders are expected on days when bad news predominates.

\subsubsection{Herding effect and investor sentiment}

Tables 10 and 11 present the results of the asymmetry tests for the investor sentiment index, based on their optimistic and pessimistic views and how this affects market prices. Xavier and Machado (2017) commented that the analysis of this index in the Brazilian market is new and should be deepened, but it can influence the pricing of all assets. In both cases, the coefficient indicating herding effect is not significant. What differs in the analyses is that the coefficient $\beta 2$ in Table 10 is positive and that in Table 11 is negative. However, in the absence of statistical significance, this fact does not determine the existence of herd behavior, which suggests the noninterference of investor sentiment in the effect.

\subsection{Discussion OF THE RESUlTS}

Table 12 consolidates the results and shows that the occurrence of herding behavior in the period studied was associated with the high trading volume, high volatility, market downturn and trading imbalance by sellers. 
Table 10

Results of the CSAD model considering positive investor sentiment

\begin{tabular}{llllll}
\hline & \multicolumn{1}{c}{ Coefficient } & \multicolumn{1}{c}{ P-Value } & Residual Diagnostics & \\
\hline Intercept & 0.001468 & 0.0873 & Durbin-Watson & 2.0188537 & Do not reject H0 \\
$\beta 1$ & -0.10767 & 0.4194 & Breusch-Godfrey & 0.9512567 & Do not reject H0 \\
$\beta 2$ & 2.694552 & 0.4842 & Breusch-Pagan & $7.25 \mathrm{E}-01$ & Do not reject H0 \\
\hline
\end{tabular}

Source: Research data (2018)

Table 11

Results of the CSAD model considering negative investor sentiment

\begin{tabular}{llllll}
\hline & \multicolumn{1}{c}{ Coefficient } & \multicolumn{1}{l}{ P-Value } & Residual Diagnostics & \\
\hline Intercept & 0.0014205 & 0.0742 & Durbin-Watson & 2.4072067 & Reject H0 \\
$\beta 1$ & -0.0430257 & 0.6171 & Breusch-Godfrey & 0.0277101 & Reject H0 \\
$\beta 2$ & -2.0768069 & 0.1567 & Breusch-Pagan & $9.45 \mathrm{E}-55$ & Reject H0 \\
\hline
\end{tabular}

Source: Research data (2018)

Table 12

Summary results of the herding behavior

\begin{tabular}{lcc}
\hline Fundamental Factor & $25 \%$ Highest & $25 \%$ Lowest \\
\hline Trading Volume & Herding & No Herding \\
Volatility & Herding & No Herding \\
Stock Returns & No Herding & Herding \\
Sentiment & No Herding & No Herding \\
TIP & No Herding & Herding \\
\hline
\end{tabular}

Source: Research data (2018)

The results corroborate Christie and Huang (1995), Silva and Lucena (2018), Chiang and Zheng (2010) and Bhaduri and Mahapatra (2013), who argued that herding is more likely to happen in times of market downturns, because this generates uncertainty of investors and they choose to follow the decisions of others. These findings show that after good past performance and in a higher proportion of buyer-initiated orders, investors are less prone to act in synchrony. The main contribution of the paper is to identify that herding behavior reacts asymmetrically to the sign of the past shocks. Negative returns imply higher volatility (Black, 1976). Along with high trading volume and trading imbalance skewed to sellers, this suggests that herd behavior occurred only after market downturns.

\section{CONCLUSIONS}

The objective of this article was to investigate the occurrence of the herding effect in the Brazilian stock market and its relationship with variables that represent market status.

We tested the relationships between the identified herding effect periods and daily trading volume, volatility, both good and poor market performance, investor sentiment, and imbalance 
between buy and sell orders. The results suggested that herding behavior depends on high trading volume, high volatility of returns, market downturn, and trading imbalance triggered by sellers.

The results of high trading volume suggest the existence of a group of investors that affect the decisions of others. The same does not happen for assets with low volume. In relation to periods of higher volatility, the behavior is attributed to the uncertainty generated in market agents. The occurrence of the herding effect in market downturns highlights the link between the herding effect and periods of crisis. These results corroborate the assumptions that agents are more likely to imitate others when facing periods of imminent loss. Finally, it was not possible to verify the presence of the herding effect related to periods of high and low investor sentiment. In relation to the misbalancing of orders, the herding effect was only found when the market imbalance was motivated by sell orders. This suggests that an intense movement of selling can generate uncertainty in agents, causing them to get rid of their shares. The results are important to the extent that they highlight a behavioral phenomenon that opposes modern portfolio theory.

\section{REFERENCES}

Almeida, R. (2011) O comportamento manada em mercados acionários Latino-Americanos. Dissertação (Mestrado em Administração) - Programa de Pós-Graduação em Administração, UFSC, Florianópolis, 2011. https://repositorio.ufsc.br/bitstream/handle/123456789/95396/290155. pdf? sequence $=1$ \&isAllowed $=\mathrm{y}$.

Araujo Neto, L. M.; Freire, F. S. Comportamento Manada: Estudo aplicado em estudando do curso de ciências contábeis. Revista de Informação Contábil-RIC, 7(1), 23-34.

Araujo Neto, L. M. (2016) Efeito manada no mercado de capitais: um estudo com gerentes de bancos públicos do Distrito Federal. RACE, Revista de Administração, Contabilidade e Economia, 15(2), 601-620

Argolo, E.F.B., Leal, R.P.C., \& Almeida, V. S. (2012). O modelo de Fama e French é aplicável no Brasil? Rio de Janeiro: COPPEAD.

Banerjee, A. (1992) A Simple model of herd behavior. The Quarterly Journal of Economics, 107(3), 797-817

Bhaduri, S.; Mahapatra, S. (2013) Applying an alternative test of herding behavior: A case study of the Indian stock Market. Journal of Asian Economics, 25, 43-52, 2013. https://doi.org/10.1016/j. asieco.2013.02.001

Black, F. (1976). Studies in stock price volatility changes. Proceedings of the 1976 Meeting of the Business and Economic Statistics Section, American Statistical Association, pp. 177-181.

Chang, E., Cheng, J. and Khorona, A. (2000) An examination of Herding behavior in equity markets: an international perspective. Journal of Banking \& Finance, 24, pp. 1651-1679, 2000. https://doi. org/10.2139/ssrn. 181872

Chiang T., Zheng, D. (2010). An empirical analysis of herd behavior in global stock markets. Journal of Banking \& Finance, 34(8), 1911-1921.

Chordia, T., Roll R., Subrahmanyam A. (2002) Order imbalance, liquidity and market returns. Journal of Financial Economics 65, 111-130. https://doi.org/10.1016/S0304-405X(02)00136-8

Chordia, T., Roll R., Subrahmanyam A. (2004) Evidence on the speed of convergence to market efficiency. Journal of Financial Economics 76, 271-292. https://doi.org/10.1016/j.jfineco.2004.06.004 
BBR

18
Christie, W.G., Huang, R.D. (1995) Following the pied piper: Do individual returns herd around the market? Financial Analysts Journal, 31-37. https://doi.org/10.2469/faj.v51.n4.1918

Cipriani, M., Guarino, A. Herding behavior and Contagion in Financial Markets. Institute for International Economic Policy Working Paper Series. IIEP $\neg$ WP $\neg 2010 \neg 1$

Cont, R., Kubanov, A., Stoikov, S. (2014) The price impact of order book events. Journal offinancial econometrics, 12(1), 47-88, 2014. https://doi.org/10.1093/jjfinec/nbt003

Devenow, A., Welch, I. (1996) Rational herding in financial economics. European Economic Review 40, 603-615.

Hachicha, N. (2020) New Sight of herding behavioural through trading volume. Economics Discussion Papers. Available in: http://www.economics-ejournal.org/economics/discussionpapers/2010-11.

Hwang, S. Salmon, M. A. (2001) New Measure of Herding and Empirical Evidence. Financial Econometrics Research Centre - Working Paper Series. London. https://doi.org/10.1.1.11.9488

Hwang, S. Salmon, M. (2004) Market Stress and Herding. Journal of Empirical Finance, 11, n. 4, 585-616. https://doi.org/10.1016/j.jempfin.2004.04.003

Kyle, A. (1985) Continuous auctions and insider trading. Econometrica 53, 1315-1335. https://doi. org/10.2307/1913210

Kutchukian, E. (2010). O efeito manada nos fundos de investimento no Brasil: um teste em finanças comportamentais. Dissertação (mestrado) - Fundação Getúlio Vargas - Escola de Administração de Empresas de São Paulo, São Paulo. http://bibliotecadigital.fgv.br/dspace/handle/10438/4921.

Lakonishok, J., Shleifer, A. and Vishny, R. W. (1992) The impact of institutional trading on stock prices, Journal of Financial Economics, 32, 23-43. https://doi.org/10.1016/0304-405X(92)90023-Q.

Liang, B. (2017) Uma investigação do efeito manada nos fundos de investimento imobiliário brasileiros. Dissertação (mestrado) - Escola de Administração de Empresas de São Paulo, Fundação Getúlio Vargas - (FGV). http://hdl.handle.net/10438/19521.

Majerowicz, I. (2017) Houve efeito manada no Mercado de açóes brasileiro entre 2010 e 2015 Uma análise a partir do modelo de CCK. Dissertação (mestrado) - Pontifícia Universidade Católica do Rio de Janeiro - PUC. Rio de Janeiro. http://www2.dbd.puc-rio.br/pergamum/ tesesabertas/1512735_2017_completo.pdf.

Martins, O. S.; Paulo, E.; Albuquerque, P. H. M. (2013) Negociação com informação privilegiada e retorno das açóes na BM\&FBovespa. Revista de Administração de Empresas, 53(4), 350-362. https://doi.org/10.1590/S0034-75902013000400003

Pereira, G.; Camilo-Da-Silva, E; Barbedo, C. (2020) Trading Imbalance, Liquidity and Stock Returns: Evidence from Brazil. Latin American Business Review. https://doi.org/10.1080/10978526.2019 .1701482

Rajan, R.G. (1994) Why credit policies fluctuate: A theory and some evidence. Quarterly Journal of Economics 436, 399-442.

Scharfstein, D.S., Stein, J.C. (1990) Herding behavior and investment. American Economic Review $80,465-479$.

Silva, J.; Barbedo, C.; Araújo, G. (2015) Há Efeito Manada em Açóes com Alta Liquidez do Mercado Brasileiro? Banco Central, Brasília. http://www.bcb.gov.br/pec/wps/port/TD386.pdf. 
Silva, V. (2017) Finanças Comportamentais: Análise dos Fatores do Efeito Manada em Empresas Listadas na [B]3-Brasil Bolsa Balcão. Dissertação (mestrado) - Universidade Federal da Paraíba. João Pessoa - Paraíba. https://repositorio.ufpb.br/jspui/bitstream/123456789/1933/1/VMS04092017.pdf.

Silva, V; Lucena, W. (2018) Finanças Comportamentais: Análise dos Fatores do Efeito Manada em Empresas Listadas na [B]3-Brasil Bolsa Balcão. XVIII USP Internacional Conference in Accounting. São Paulo, jul. 2018. Available in www.congressousp.fipecafi.org.

Tariki, F. (2014). Evidência do efeito manada em fundos de renda variável na indústria de fundos brasileira. Dissertação (mestrado) - Fundação Getúlio Vargas - FGV. São Paulo. http://hdl.handle. net/10438/12001.

Wermers, R. (1995) Herding, Trade Reversals, and Cascading by Institutional Investors. University of Colorado, Boulder.

Xavier, G. C; Machado, M. A. V. Anomalias e Sentimento do Investidor: Evidências Empíricas no Mercado Brasileiro. Revisão da Administração Brasileira, 14(3). http://www.scielo.br/scielo. php?script=sci_arttext\&pid=S1807-76922017000300302.

Zulian, B, Kimura, H. Basso, L. (2012) Estudo de Índices de Comportamento de Manada em Fundos Brasileiros de Investimentos em Açóes. Revista Alcance, 19,(1), https://doi.org/10.14210/ alcance.v19n1.p07-23.

\section{AUTHORS CONTRIBUTIONS}

PFCLS - Contributed mainly with problem definition, hypotheses development, literature review, results and analysis. EC-S - Contributed mainly with problem definition, hypotheses development, method, results and conclusions.

CHSB - Contributed mainly with problem definition, hypotheses development, method and discussion.

\section{CONFLICTS OF INTEREST}

The authors state that there are no conflicts of interests. 
BBR

18

254

\section{NOTES}

${ }^{1}$ This area of study is known as market microstructure, an area that analyzes the influence of trading mechanisms on the formation of equilibrium prices. The imbalance between buy and sell transactions in the stock market was verified through the index called TIP (Trade Imbalance Picture) according to Pereira, Camilo-da-Silva and Barbedo (2020). 